\title{
In vitro activity of the hydroalcoholic extract of Chenopodium ambrosioides against engorged females of Rhipicephalus (Boophilus) microplus
}

\section{Atividade in vitro do extrato hidroalcoólico de Chenopodium ambrosioides diante de teleóginas de Rhipicephalus (Boophilus) microplus}

\author{
Eduardo Oliveira ${ }^{1 *}$, Manoela da Silva², Lew Sprenger², Daniela Pedrassani²

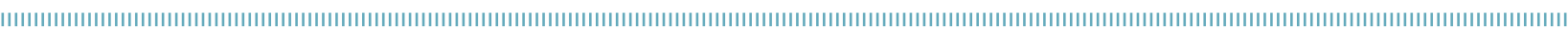

\begin{abstract}
Rhipicephalus (Boophilus) microplus, known as the cattle tick, is a cause of great economic losses for dairy cattle farming because of its high frequency of occurrence and the difficulty in controlling it. The aim of this study was to evaluate the in vitro activity of Chenopodium ambrosioides extract on $R$. (B.) microplus. For this purpose, 125 females were selected and classified into five groups according to their weight, in order to ensure that the females used presented homogeneous weight. The treatments comprised 40 and 60\% extracts of Chenopodium ambrosioides, distilled water, ethanol $\left(70^{\circ} \mathrm{GL}\right)$ and $12.5 \%$ amitraz. The extracts of $C$. ambrosioides (40 and 60\%) showed effectiveness of 99.7 and 100\% and higher percentages of dead females than the other treatments: 64 and $96 \%$, respectively $(\mathrm{p}<0.001)$. In the groups exposed to distilled water and ethanol ( $\left.70^{\circ} \mathrm{GL}\right), 92$ and $88 \%$ of the females maintained oviposition. In the females exposed to 40 and $60 \%$ extracts, oviposition of 36 and $4 \%$ occurred, respectively. It was concluded that the extract of Chenopodium ambrosioides, at both concentration evaluated, had high efficiency against engorged females of cattle ticks.
\end{abstract}

KEYWORDS: Santa Maria herb; phytotherapy; cattle tick.
RESUMO: O carrapato Rhipicephalus (Boophilus) microplus, popularmente conhecido como carrapato-do-boi, é responsável por grande prejuízo à pecuária leiteira, em razão da sua alta frequência e dificuldade em seu controle. O objetivo do estudo foi avaliar a atividade in vitro do extrato hidroalcóolico de Chenopodium ambrosioides sobre teleóginas de $R$. (B.) microplus. Para tal, foram selecionadas 125 teleóginas, classificadas em cinco tratamentos de acordo com o peso, de forma a manter os pesos das fêmeas homogêneos. Os tratamentos foram constituídos por: extrato hidroalcoólico da planta nas concentraçóes de 40 e $60 \%$ (v/v); água destilada; etanol $70^{\circ} \mathrm{GL}$; e amitraz 12,5\%. Os extratos de C. ambrosioides nas concentraçôes de 40 e 60\% demonstraram eficácia de 99,7 e $100 \%$ e porcentagem de fêmeas mortas superior à dos demais tratamentos: 64 e $96 \%$, respectivamente $(\mathrm{p}<0,001)$. Nos grupos tratados com água destilada e etanol $70^{\circ} \mathrm{GL}, 92$ e $88 \%$ das fêmeas realizaram postura. Nas fêmeas expostas ao extrato 40 e $60 \%$, a postura ocorreu em 36 e 4\%, respectivamente. Conclui-se que o extrato hidroalcoólico de $C$. ambrosioides, nas concentraçóes avaliadas, possui alta eficiência contra teleóginas do carrapato bovino.

PALAVRAS-CHAVE: erva-de-santa-maria; fitoterapia; carrapato bovino.

\footnotetext{
'Universidade Sociedade Educacional de Santa Catarina (UNISOCIESC) - São Bento do Sul (SC), Brazil. ${ }^{2}$ Universidade do Contestado (UnC) - Canoinhas (SC), Brazil.

*Corresponding author: eduardovetufpr@gmail.com

Received on: 03/22/2016. Accepted on: 10/11/2017
} 


\section{INTRODUCTION}

A variety of factors influences the degree of success in cattle rearing. These may be genetic or environmental factors, technological advances applied to animal production, nutritional management or health management in the herd. Regarding animal health, problems with ectoparasites have gained prominence and are a matter of concern because of the production losses that it can lead to. It has been estimated that $80 \%$ of the worldwide cattle population is exposed to the tick Rhipicephalus (Boophilus) microplus. This ectoparasite is responsible for diminished leather quality, disease transmission (PATARROYO; LOMBANA, 2004), weight loss, worsened feed conversion and decreased milk production (SANTOS et al., 2013).

In Brazil, this tick is responsible for annual losses of 3.24 billion dollars (GRISI et al., 2014), and it presents resistance to the great majority of pesticides available on the market because of their uncontrolled use. Utilization of these pesticides leads to toxicity and losses of meat quality and production levels. Moreover, there is concern within society and government bodies regarding pesticide residues in milk and concern regarding the environmental damage caused by inappropriate use of these products (CHAGAS et al., 2002).

Thus, a need has arisen to seek alternative methods for tick control that would present high efficiency, low cost and absence of resistance. In seeking such methods, many plant species have already been used in the form of extracts. These include: Copaifera reticulata (FERNÁNDEZ-SALAS, 2011); Petiveria alliacea (ROSADO-AGUILAR et al., 2010); Cuminum cyminum, Pimenta dioica and Ocimum basilicum (MARTINEZ-VELAZQUEZ et al., 2011a); Carapa guianensis, Cymbopogon martinii, Cymbopogonschoenanthus and Piper tuberculatum (CHAGAS et al., 2012); Manilkara zapota (RAJAKUMAR; RAHUMAN, 2012); Lippia graveolens, Rosmarinus officinalis and Allium sativum (MARTINEZ-VELAZQUEZ et al., 2011b); and Calea serrata (RIBEIRO et al., 2008).

The plant Chenopodium ambrosioides, known as St. Mary's herb, is commonly found in southern Brazil. It has been studied because of its anthelmintic properties (PEREZGROVAS et al., 1994), fungicidal properties (KUMAR et al., 2007), anti-protozoan properties (MONZOTE et al., 2006), insecticidal properties (REIS et al., 2010) and even acaricidal properties (SANTOS et al., 2013; POZZATTI et al., 2012; ALMANÇA et al., 2013). Thus, the objective of this study was to evaluate the effect of extracts of $C$. ambrosioides on teleogynes (engorged females) of Rhipicephalus (Boophilus) microplus.

\section{MATERIAL AND METHODS}

\section{Obtaining the extracts}

C. ambrosioides plants (consisting of leaves, stalks and flowers) were gathered in the municipality of Canoinhas, Santa
Catarina, and were subsequently identified in the laboratory at the University of Contestado. They were then dried in a heated chamber at $40^{\circ} \mathrm{C}$ for 7 days and ground up in an electric milling machine. Following this, the material was mixed with ethanol $\left(70^{\circ} \mathrm{GL}\right)$ in the proportions $1: 12$, and this mixture was left in a receptacle sealed using aluminum foil, to be macerated for 20 minutes. After this period, the material was filtered through a paper filter, and the liquid thus collected was placed in a water bath at $42^{\circ} \mathrm{C}$ and was left there for 21 days. This yielded a crude extract, which was then diluted in distilled water to produce concentrations of 40 and $60 \%$, for use in in vitro bioassays.

Qualitative phytochemical screening was performed at the Paraná Center for Scientific and Educational Research on Medicinal Plants (NUPPLAMED), in accordance with the methodology described by MATOS (1998). It was sought to ascertain which secondary metabolites were present: phenols, tannins, anthocyanins, anthocyanidins, leucoanthocyanidins, steroids, triterpenes, saponins, resins and alkaloids). Total phenols were assayed using the Folin-Ciocalteu test, following the adapted methodology of MCDONALD et al. (2001).

The total phenol concentration was determined through interpolation of the absorbance of the samples in comparison with a calibration curve constructed using Gallic acid standards. The results were determined from the regression equation of the calibration curve $\left(y=0.02 x-0.0064 ; R^{2}=0.9911\right)$ and were expressed in milligrams ( $\mathrm{mg}$ ) of Gallic acid equivalent per gram (g) of the sample. The toxic activity of the extract was evaluated by means of a lethality test against Artemia salina Leach, following the methodology of MEYER et al. (1982). The toxicity criteria for the extracts were established as follows: $>1,000 \mu \mathrm{g} / \mathrm{mL}$ (nontoxic); $\geq 500 \leq 1,000 \mu \mathrm{g} / \mathrm{mL}$ (weakly toxic); and $<500 \mu \mathrm{g} / \mathrm{mL}$ (toxic). An antioxidant assay was performed using the reduction method on the free radical 1,1-diphenyl-2-picrylhydrazyl (DPPH), in accordance with the methodology of Blois (1958), using ascorbic acid as the standard.

\section{Collection of teleogynes (engorged females) and bioassays}

Two hundred teleogynes of Rhipicephalus (Boophilus) microplus of length greater than $4 \mathrm{~mm}$ were collected from cattle of the breeds Friesian-Holstein, Girolando and Jersey that were naturally infected and had not been treated with acaricides for at least 60 days. From these 200 specimens, 125 that were free from malformations and lesions, and did not present remainders of skin on their buccal apparatus, were selected. These specimens were washed in distilled water, dried on absorbent paper and distributed into five homogenous treatment groups according to their weight (Table 1).

Each of the five treatments consisted of five repetitions, and repetition was composed of five teleogynes (i.e. $n=25$ specimens 
per group). The treatments were defined randomly between the five groups.

The first treatment group was exposed to distilled water (negative control), and this water was the same as used to dilute the plant extracts and the acaricide. The second treatment group was exposed to alcohol $\left(70^{\circ} \mathrm{GL}\right)$. The third treatment group was exposed to $12.5 \%$ amitraz (amidine at a concentration of $0.025 \%$ after dilution), which was a contact acaricide that had previously been tested on the farm. The fourth and fifth treatment groups comprised 40 and $60 \%$ dilutions of the hydroalcoholic extract of $C$. ambrosioides, respectively.

The teleogynes were immersed for five minutes in the respective treatments. They were then dried on absorbent paper and were fixed to Petri dishes that had previously been labeled, using double-sided adhesive tape. They were kept in a chamber under biochemical oxygen demand (BOD) conditions at $27^{\circ} \mathrm{C}( \pm 1)$ and $80 \%$ relative humidity $( \pm 5)$. They were monitored regarding oviposition and mortality every day for the next 18 days.

On the $19^{\text {th }}$ day after the start of the experiment, the egg masses were removed from the Petri dishes and were weighed and transferred to glass test tubes that were sealed using gauze and labeled. After an incubation period of 15 days, the percentage hatching of the eggs in each group was estimated.

\section{Data collection}

The following data were recorded and evaluated: mean weight of oviposition (g); weight of the teleogynes (g); percentage of dead females (positive or negative reaction to touching them with tweezers); percentage hatching after 15 days; percentage of the teleogynes that presented oviposition; reproductive efficiency (RE, \%); and treatment efficiency (TE, \%).
The reproductive efficiency (RE) and treatment efficiency (TE) were calculated using the methodology suggested by DRUMMOND et al. (1973): RE = ( (weight of eggs (g)/weight of teleogynes $(\mathrm{g})) \times \%$ hatching $\left.\times 20,000^{*}\right)$; and TE $=((\mathrm{RE}$ of the control group $-\mathrm{RE}$ of the treated group) / RE of the control group) $\times 100$.

\section{Statistical analysis}

The variables were subjected to the Shapiro-Wilk normality test. Since none of the variables presented normal distribution, the nonparametric Kruskal-Wallis test was used. Significant differences were deemed to exist between the treatments when $\mathrm{p} \leq 0.05$.

\section{RESULTS AND DISCUSSION}

In a study conducted by ALMANÇA et al. (2013), extracts of Chenopodium ambrosioides at concentrations of 5, 10 and 25\% were shown to be inefficient on teleogynes of Rhipicephalus (Boophilus) microplus. These authors therefore suggested that higher concentrations should be used.

In the present study, on the day after the teleogynes had been immersed in the treatments, $52 \%$ of the females treated with the $60 \%$ extract had died, and the mortality rate reached $96 \%$ on the sixth day (Fig. 1, Table 1). The females treated with $40 \%$ extract presented $24 \%$ mortality at the end of the first day and $64 \%$ on the sixth day. KOUAM et al. (2015) had already reported that, at a dose of $0.12 \mu \mathrm{L} / \mathrm{g}$ in vitro, the essential oil of $C$. ambrosioides had a toxic effect on Rhipicephalus lunulatus, with high mortality

Table 1. Mean \pm standard deviation of egg weight, teleogyne weight, percentage mortality, percentage hatching, reproductive efficiency and treatment efficiency, relating to in vitro treatments of teleogynes of Rhipicephalus (Boophilus) microplus with distilled water, alcohol $\left(70^{\circ}\right)$, amitraz and 40 and $60 \%$ extracts of $C$. ambrosioides, which were maintained under biochemical oxygen demand $(B O D)$ conditions at a temperature of $27^{\circ} \mathrm{C}( \pm 1)$ and $80 \%$ relative humidity $( \pm 5)$.

\begin{tabular}{|c|c|c|c|c|c|c|}
\hline Treatment & $\begin{array}{l}\text { Teleogyne } \\
\text { weight }(g)\end{array}$ & $\begin{array}{l}\text { Mean weight of } \\
\text { oviposition }(g)^{*}\end{array}$ & Mortality (\%)* & $\begin{array}{c}\text { Percentage } \\
\text { hatching }(\%)^{*}\end{array}$ & $\begin{array}{l}\text { Reproductive } \\
\text { efficiency* }\end{array}$ & $\begin{array}{l}\text { Treatment } \\
\text { efficiency* } \\
\text { (\%) }\end{array}$ \\
\hline Distilled water & $0.748 \pm 0.008$ & $0.272 \pm 0.040^{a}$ & $8.00 \pm 10.95^{a}$ & $89.00 \pm 4.18^{a}$ & $\begin{array}{c}651,159.0 \pm \\
81,095.0^{a}\end{array}$ & - \\
\hline Ethanol $\left(70^{\circ}\right)$ & $0.744 \pm 0.015$ & $0.232 \pm 0.050^{b}$ & $12.00 \pm 17.88^{a}$ & $85.99 \pm 7.90^{a}$ & $\begin{array}{c}527,267.0 \pm \\
93,680.0^{a}\end{array}$ & $19.02 \pm 14.38^{a}$ \\
\hline Amitraz & $0.744 \pm 0.011$ & $0.003 \pm 0.000^{c}$ & $0.00 \pm 0.00^{a}$ & $0.00 \pm 0.00^{b}$ & $0.0 \pm 0.0^{b}$ & $100.00 \pm 0.00^{b}$ \\
\hline $\begin{array}{l}40 \% \text { extract of } \\
\text { C. ambrosioides }\end{array}$ & $0.740 \pm 0.007$ & $0.024 \pm 0.020^{c d}$ & $64.00 \pm 21.91^{b}$ & $2.00 \pm 2.74^{b}$ & $\begin{array}{l}1,637.0 \pm \\
3,218.0^{b}\end{array}$ & $99.75 \pm 0.50^{b}$ \\
\hline $\begin{array}{l}60 \% \text { extract of } \\
\text { C. ambrosioides }\end{array}$ & $0.738 \pm 0.008$ & $0.03 \pm 0.00^{d}$ & $96.00 \pm 8.94^{b}$ & $0.00 \pm 0.00^{b}$ & $0.00 \pm 0.00^{b}$ & $100.00 \pm 0.00^{b}$ \\
\hline
\end{tabular}

*Different letters in the columns indicate significant differences $(P<0.05)$ according to the Kruskal-Wallis test. 
rates of approximately $50 \%$ after 24 hours and $100 \%$ on the fourth day. In addition to the acaricidal effect of this plant, the mortality among the teleogynes exposed to the $60 \%$ extract may have been increased through the high viscosity of the solution, which may have occluded the peritreme, thus making it difficult for them to breathe.

The mortality in the control groups was low. On the $18^{\text {th }}$ day, the distilled water, ethanol $\left(70^{\circ} \mathrm{GL}\right)$ and amitraz groups showed mortality rates of 8,12 and $0 \%$, respectively. The lack of mortality due to amitraz (amidine) was expected, given that this substance has a high effect on oviposition and larval hatchability (ANDREOTTI, 2010; SPINOSA et al., 2006). These results suggest that six days is the time needed for the 40 and $60 \%$ extracts of $C$. ambrosioides to cause almost complete mortality among the teleogynes of R. (Boophilus) microplus.

Regarding efficiency, the groups treated with the extracts of $C$. ambrosioides and amitraz showed a significant difference in comparison with those ones treated with distilled water and ethanol (70 $\mathrm{GL}$ ) (Fig. 2, Table 1). The hydroalcoholic extracts of $C$. ambrosioides presented very high efficiency: even at the lower concentration of $40 \%$, efficiency of $99.75 \%$ was achieved, while the $60 \%$ extract showed $100 \%$ efficiency. Thus, these extracts can be considered for use as an alternative acaricide treatment, and not just as complementary therapy. Nonetheless, it would also be instructive to evaluate lyophilized extracts, to observe whether there might be any difference in the results.

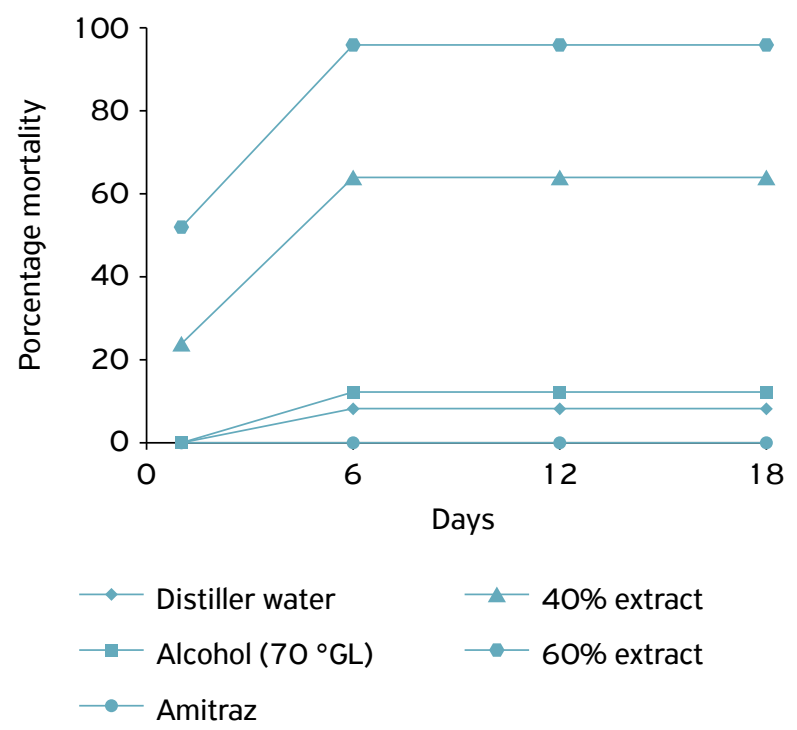

Figure 1. Mortality (\%) on the $1^{\text {st }}, 6^{\text {th }}, 12^{\text {th }}$ and $18^{\text {th }}$ days among the teleogynes of Rhipicephalus (Boophilus) microplus that were treated in vitro with distilled water, alcohol $\left(70^{\circ}\right)$, amitraz and 40 and $60 \%$ extracts of $C$. ambrosioides and maintained under biochemical oxygen demand (BOD) conditions at a temperature of $27^{\circ} \mathrm{C}( \pm 1)$ and $80 \%$ relative humidity $( \pm 5)$.
Regarding the oviposition performed by the teleogynes in the different groups, the groups treated with the extracts and amitraz showed a significant difference $(\mathrm{p}<0.05)$ in the mean weight of oviposition (g) in comparison with those ones treated with distilled water and ethanol $\left(70^{\circ} \mathrm{GL}\right)$. The percentage hatching and reproductive efficiency were lower in the groups treated with the 40 and 60\% extracts and with amitraz $(\mathrm{p}<0.05)$.

These results demonstrate that, at both concentrations evaluated, the extracts were efficient for inhibiting oviposition and the hatchability of the eggs, with an effect similar to that of amitraz. Nonetheless, although amitraz demonstrated treatment efficiency, reproductive efficiency and percentage hatching equal to those of the two concentrations of the extract, the higher percentage mortality among the teleogynes that was observed with both the 40 and the $60 \%$ extract indicates that these extracts acted more efficiently on the teleogynes of Rhipicephalus (Boophilus) microplus.

Regarding the percentage of the teleogynes that presented oviposition, 92 and $88 \%$ of those ones that were treated with distilled water and ethanol $\left(70^{\circ} \mathrm{GL}\right)$ respectively achieved oviposition with completely viable eggs. From the treatment with amitraz, only $4 \%$ of the teleogynes achieved oviposition, and $100 \%$ of these eggs were unviable. Among the engorged females treated with the $40 \%$ extract, $36 \%$ achieved oviposition; and among those treated with the $60 \%$ extract, only $4 \%$ achieved oviposition (Fig. 3). Regarding the appearance of the eggs, the females

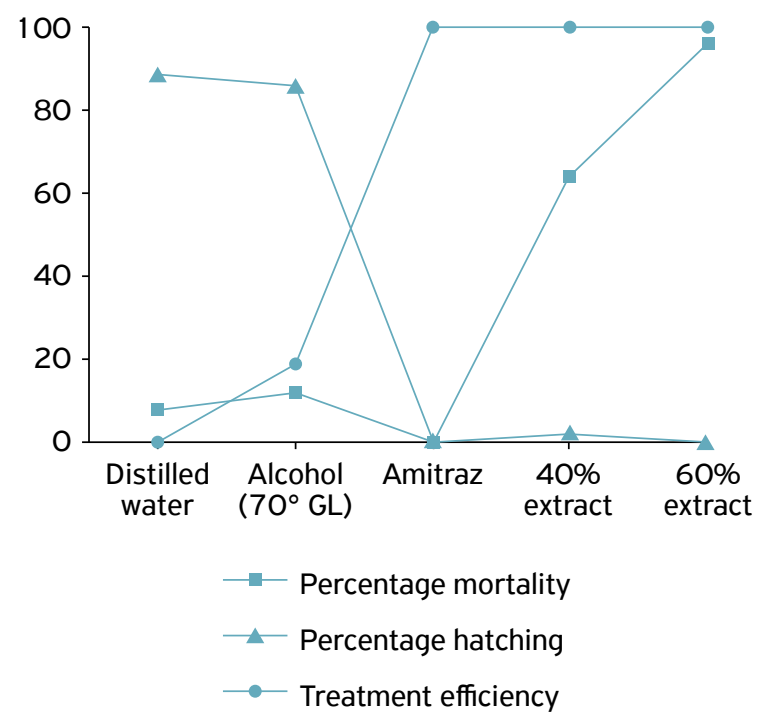

Figure 2. Percentage mortality, percentage hatching and treatment efficiency, relating to in vitro treatments of teleogynes of Rhipicephalus (Boophilus) microplus with distilled water, alcohol $\left(70^{\circ}\right)$, amitraz and 40 and $60 \%$ extracts of $C$. ambrosioides, which were maintained under biochemical oxygen demand (BOD) conditions at a temperature of $27^{\circ} \mathrm{C}( \pm 1)$ and $80 \%$ relative humidity $( \pm 5)$. 
that performed oviposition after treatments with distilled water and ethanol $\left(70^{\circ} \mathrm{GL}\right)$ produced shiny brown-colored eggs, thus indicating fertility. The teleogynes treated with the 40 and $60 \%$ extracts produced darker eggs of matt appearance, while those ones treated with amitraz only produced a yellow secretion.

Differing from what was observed in the present study, ALMANÇA et al. (2013) reported that the 5, 10 and 25\% extracts of $C$. ambrosioides did not have any influence on the larval hatching of $R$. (B.) microplus, or consequently on reproductive efficiency. POZZATTI et al. (2012) evaluated the reproductive efficiency and treatment efficiency resulting from use of fluid extracts $(5,10$ and $25 \%)$ and glycolic extracts (10, 20,30 and $50 \%$ ) on C. ambrosioides. They reported that there were high percentages of hatchability from all the treatments (between 93.5 and 99\%) and low treatment efficiencies (between 1.5 and $34.82 \%$ ), thus indicating that the extracts of C. ambrosioides only had a small effect. The difference in the results observed between the present study and those in the literature can be ascribed to the differences in extract preparation methods and in the concentrations of the product used.

For antiparasitic products to be licensed for veterinary use by the Brazilian agricultural protection bodies, the minimum criterion is that they need to present mean efficiency of $95 \%$ (BRASIL, 1997), which was seen in relation to the 40 and $60 \%$ extracts of $C$. ambrosioides. Nonetheless, although the extracts of $C$. ambrosioides presented an in vitro effect on the teleogynes of $R$. (Boophilus) microplus regarding oviposition

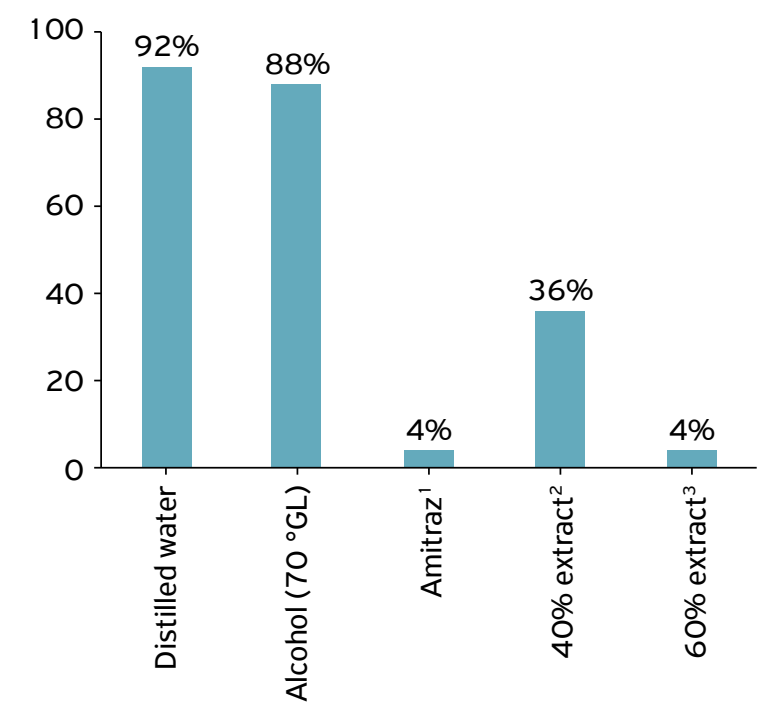

$14 \%$ of the teleogynes performed oviposition with unviable eggs; ${ }^{2} 36 \%$ performed partial oviposition; ${ }^{3} 4 \%$ performed unviable oviposition.

Figure 3. Percentage oviposition among the teleogynes of Rhipicephalus (Boophilus) microplus that were treated in vitro with distilled water, alcohol $\left(70^{\circ}\right)$, amitraz and 40 and $60 \%$ extracts of $C$. ambrosioides and maintained under biochemical oxygen demand (BOD) conditions at a temperature of $27^{\circ} \mathrm{C}$ $( \pm 1)$ and $80 \%$ relative humidity $( \pm 5)$. and egg hatchability, studies evaluating the viability of using these extracts in vivo are necessary, given that the high concentration and viscosity of the product may cause difficulty in producing and applying it.

\section{Phytochemical screening}

The phytochemical screening demonstrated the presence of substances that may have positive effects in relation to combating ticks, such as phenols, tannins, catechins, steroids, triterpenes, resins and alkaloids (Table 2). Phenols are substances used in disinfectants, since they cause inactivation of the enzyme system and loss of essential metabolites through the cell wall, with a spectrum of bactericidal, fungicidal, viricidal and tuberculocidal action (GOVERNO DO ESTADO DA BAHIA, 2001). Catechins and steroids are considered to be potent allelopathic agents (RODRIGUES et al., 2009; LÔBO et al., 2008), i.e., they produce secondary metabolites that may alter the growth and/or development of other biological systems. Triterpenes and alkaloids have been reported to have larvicidal and ovicidal effects on insects (MACIEL et al., 2006).

Tannins have been used for treating a variety of illnesses, including diarrhea, arterial hypertension, rheumatism, hemorrhages, wounds, burns, renal problems and inflammatory processes (MARTINS et al., 2007). The effects of

Table 2. Result from phytochemical screening of the hydroalcoholic extract obtained from the plant Chenopodium ambrosioides.

\begin{tabular}{|c|c|c|}
\hline Test or reagent & Compound & Effect* \\
\hline \multirow{2}{*}{ Ferric chloride } & Phenols & + \\
\hline & Tannins & + \\
\hline $\begin{array}{l}\text { Gelatin }(2,5 \% \text { w/v), } \mathrm{NaCl} \\
0.9 \% \text { w/v }\end{array}$ & Tannins & + \\
\hline \multirow{2}{*}{ Change of $\mathrm{pH}$} & Anthocyanins & - \\
\hline & Anthocyanidins & - \\
\hline \multirow{2}{*}{$\begin{array}{l}\text { Change of } \mathrm{pH} \text { and } \\
\text { heating }\end{array}$} & Catechins & - \\
\hline & Leucocyanidins & - \\
\hline Wood, $\mathrm{HCl}$ and heating & Catechins & + \\
\hline Liebermann-Burchard & Steroids & + \\
\hline $\mathrm{H}_{2} \mathrm{SO}_{4}$ and anisaldehyde & Triterpenes & + \\
\hline Chloroform & Saponins & - \\
\hline Ethanol & Resins & + \\
\hline Dragendorff & Alkaloids & + \\
\hline Folin-Ciocalteu & Total phenols & $\begin{array}{c}84.000 \pm \\
0.689 \mu \mathrm{g} / \mathrm{L}\end{array}$ \\
\hline Toxicity & Artemia salina & $1.058 \mu \mathrm{g} / \mathrm{mL}$ \\
\hline
\end{tabular}

*Effect: + positive reaction; - negative reaction. 
tannin-rich plants (Acacia pennatula, Piscidia piscipula, Leucaena leucocephala and Lysiloma latisiliquum) were studied by FERNÁNDEZ-SALAS et al. (2011), who found that their aqueous extracts at a concentration of $1.92 \%$ presented efficiencies of 35, 39.21, 29 and 69.34\%, respectively, on teleogynes of $R$. (B.) microplus.

In the present study, the presence of catechins, steroids, terpenes and tannins in C. ambrosioides may have been responsible for the low egg weight, low percentage hatching, high percentage mortality and low reproductive efficiency among the teleogynes.

\section{CONCLUSIONS}

The two concentrations of hydroalcoholic extract produced from the plant Chenopodium ambrosioides that were evaluated here demonstrated high efficiency against teleogynes of Rhipicephalus (Boophilus) microplus. They interfered with oviposition and egg hatchability and can thus be considered to be acaricidal products. They also caused changes to reproductive capacity. Therefore, it can be suggested that the 40 and $60 \%$ extracts from Chenopodium ambrosioides can be used as an alternative for controlling cattle ticks.

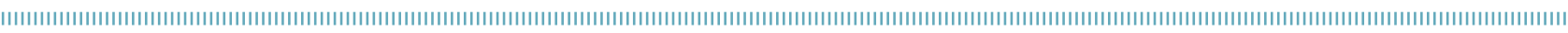
REFERENCES

ALMANÇA, C.C.J.; POZZATTI, P.N.; CASAGRANDE, F.P.; SILVA FILHO, J.P.; BISSI, B.; BARBOSA, B.C.; PORFÍRIO, L.C. Eficácia in vitro de extratos de Chenopodium ambrosioides sobre teleóginas de Rhipicephalus (Boophilus) microplus. Arquivos do Instituto Biológico, São Paulo, v.80, n. 1, p.43-49, 2013.

ANDREOTTI, R. Situação atual da resistência do carrapato-doboi Rhipicephalus (Boophilus) microplus aos acaricidas no Brasil. Campo Grande: EMBRAPA Gado de Corte, 2010. n.180.

BLOIS, M.S. Antioxidant determinations by the use of a stable free radical. Nature, v.181, p.1199-1200, 1958.

BRASIL. Ministério da Agricultura, Pecuária e Abastecimento. Portaria Ministerial n. 48, de 12 de maio de 1997. Aprova o Regulamento Técnico para licenciamento e ou renovação de licença de produtos antiparasitários de uso veterinário. Diário Oficial da União, Seção 1, Página 10165, 1997. Available from: <http:// sistemasweb.agricultura.gov.br/sislegis/action/detalhaAto.do?m ethod=visualizarAtoPortalMapa\&chave $=72818869>$. Accessed on: Feb. 25, 2016.

CHAGAS, A.C.S.; BARROS, L.D.; COTINGUIBA, M.F.; FURLAN, M.; GIGLIOTI, R.; OLIVEIRA, M.C.S.; BIZZO, H.R. In vitro efficacy of plant extracts and synthesized substances on Rhipicephalus (Boophilus) microplus (Acari: Ixodidae). Parasitology Research, v. 110, p.295-303, 2012.

CHAGAS, A.C.S.; PRATES, H.T.; LEITE, R.C.; FURLONG, J. Ação larvicida de derivados arilsulfonílicos da (+) -cânfora e da (+) -isopinocanfona, em Boophilus microplus. Arquivo Brasileiro de Medicina Veterináriae Zootecnia, Belo Horizonte, v.54, n.5, p.462-467, 2002.

DRUMMOND, R.O.; ERNST, S.E.; TREVINO, J.L.; GLADNEY, W.J.; GRAHAM, O.H. Boophilus annulatus an Boophilus microplus laboratory test of inseticides. Journal of Economic Entomology, v.66, p.130-133, 1973.

FERNANDES, F.F.; FREITAS, E.P.S. Acaricidal activity of an oleoresinous extract from Copaifera reticulata (Leguminosae: Caesalpinioideae) against larvae of the southern cattle tick, Rhipicephalus (Boophilus) microplus (Acari: Ixodidae). Veterinary Parasitology, v.147, p.150-154, 2007.
FERNÁNDEZ-SALAS, A.; ALONSO-DÍAZ, M.A.; ACOSTARODRÍGUEZ, R.; TORRES-ACOSTA, J.F.; SANDOVAL-CASTRO, C.A.; RODRÍGUEZ-VIVAS, R.I. In vitro acaricidal effect of tanninrich plants against the cattle tick Rhipicephalus (Boophilus) microplus (Acari: Ixodidae). Veterinary Parasitology, v. 175, n. 1-2, p. $113-118,2011$.

GOVERNO DO ESTADO DA BAHIA. Secretaria da Saúde. Superintendência de Vigilância e Proteção da Saúde. Diretoria de Vigilância e Controle Sanitário. Manual de Biossegurança. Salvador, 2001. Available from: <http://www.ccs.saude.gov. br/visa/publicacoes/arquivos/p1_introdu\%C3\%A7\%C3\%A30. pdf>. Accessed on: Feb. 25, 2016.

GRISI, L.; LEITE, R.C.; MARTINS, J.R.S.; BARROS, A.T.M.; ANDREOTTI, R.; CANÇADO, P.H.D.; LEÓN, A.A.P.; PEREIRA, J.B.; VILLELA, H.S. Reassessment of the potential economic impact of cattle parasites in Brazil. Revista Brasileira de Parasitologia Veterinária, v.23, n.2, p.150-156, 2014.

KOUAM, M.K.; PAYNE, V.K.; MIÉGOUÉ, E.; TENDONKENG, F.; LEMOUFOUET, J.; KANA, J.R.; BOUKILA, B.; PAMO, E.T.; BERTINE, MNM. Evaluation of In Vivo Acaricidal Effect of Soap Containing Essential Oil of Chenopodium ambrosioides Leaves on Rhipicephalus lunulatus in the Western Highland of Cameroon. Journal of Pathogens, 2015. http://doi. org/10.1155/2015/516869

KUMAR, R.; MISHRA, A.K.; DUBEY, N.K.; TRIPATHI, Y.B. Evaluation of Chenopodium ambrosioides oil as a potential source of antifungal, antiaflatoxigenic and antioxidant activity. Internation. Journal of Food Microbiology, v. 1 15, p.159-164, 2007.

LÔBO, L.T.; CASTRO, K.C.F.; ARRUDA, M.S.; SILVA, M.N.; ARRUDA, A.C.; MÜLLER, A.H.; ARRUDA, G.M.S.P.; SANTOS, A.S.; SOUZA FILHO, A.P.S. Potencial alelopático de catequinas de Tachigali myrmecophyla (Leguminosae). Química Nova, São Paulo, v.31, n.3, p.493-497, 2008.

MACIEL, M.V.; MORAIS, S.M.; BEVILAQUA, C.M.L.; CAMURÇAVASCONCELOS, A.L.F., COSTA, C.T.C.; CASTRO, C.M.S. Ovicidal and larvicidal activity of Melia azedara ch extracts on Haemonchus contortus. Veterinary Parasitology, v. 140, p.98-104, 2006. 
MARTINEZ-VELAZQUEZ, M.; CASTILLO-HERRERA, G.A.; ROSARIOCRUZ, R.; FLORES-FERNANDEZ, J.M.; LOPEZ-RAMIREZ, J.; HERNANDEZ-GUITERREZ, R.; LUGO-CERVANTES, E.C. Acaricidal effect and chemical composition of essential oils extracted from Cuminum cyminum, Pimenta dioica and Ocimum basilicum against the cattle tick Rhipicephalus (Boophilus) microplus (Acari: Ixodidae). Parasitology Research, v. 108, n.481-487, 2011 a.

MARTINEZ-VELAZQUEZ, M.; ROSARIO-CRUZ, R.; CASTILLOHERRERA, G.; FLORES-FERNANDEZ, J.M.; ALVAREZ, A.H.; LUGO-CERVANTES, E. Acaricidal Effect of Essential Oils from Lippia graveolens (Lamiales: Verbenaceae), Rosmarinus officinalis (Lamiales:Lamiaceae), and Allium sativum (Liliales: Liliaceae) against Rhipicephalus (Boophilus) microplus (Acari: Ixodidae). Journal of Medical Entomology, v.48, n.4, p.822-827, 2011 b.

MARTINS, L.V.; MARTINS, G.T.; OLIVEIRA, D.A.; PIMENTA, M.A.S. Prospecção Fitoquímica Preliminar de Dimorphandra mollis Benth. (Fabaceae-Mimosoideae). Revista Brasileira de Biociências, Porto Alegre, v.5, n.2, p.828-830, 2007.

MATOS, F.J.A. Introdução à fitoquímica experimental. 2. ed. Fortaleza: EUFC, 1998.

MCDONALD, S.; PRENZLER, P.D.; ANTOLOVICH, M.; ROBARDS, K. Phenolic content and antioxidant activity of olive extracts. Food Chemistry, v.73, p.73-84, 2001.

MEYER, B.N.; FERRIGNI, N.R.; PUTNAN, J.E.; JACOBSEN, L.B.; NICHOLS, D.E.; MCLAUGHLIN, J. Brine shrimp: a convenient general bioassay for active plant constituents. Journal of Medical Plant Research, v.45, n.5, p.31-34, 1982.

MONZOTE, L.; MONTALVO, A.M.; ALMANONNI, S.; SCULL, R.; MIRANDA, M.; ABREU, J. Activity of the essential oil from Chenopodium ambrosioides grown in cuba against Leishmania amazonensis. Chemotherapy, v.52, p.130-136, 2006.

PATARROYO, J.H.; LOMBANA, C.G. Resposta imune a vacinas sintéticas anti Boophilus microplus. Revista Brasileira de Parasitologia Veterinária, v.13, p.129-134, 2004.

PEREZGROVAS, R.; PARRY, A.; PERALTA, M.; ZARAGOZA, L.; TROW, D.; PEDRAZA, P. Chiapas sheep wool production and animal health in a unique sheep breed. New Zealand Society of Animal Production, v.54, p.177-180, 1994.

POZZATTI, P.N.; PORFÍRIO, L.C.; CASAGRANDE, F.P.; VALENTIM, T.P.; BISSI, B.; BARBOSA, B.C. Avaliação in vitro da erva de santa maria sobre Boophilus microplus. Publicações em Medicina Veterinária e Zootecnia, Londrina, v.6, n.5, 2012.

RAJAKUMAR, G.; RAHUMAN, A.A. Acaricidal activity of aqueous extract and synthesized silver nanoparticles from Manilkara zapota against Rhipicephalus (Boophilus) microplus. Research in Veterinary Science, v.93, p.303-309, 2012.

REIS, M.; TRINCA, A.; FERREIRA, M.J.U.; MONSALVE-PUELLO, A.R.; GRÁCIO, M.A.A. Toxocara canis: potential activity of natural products against second-stage larvae in vitro and in vivo. Experimental Parasitology, v.126, p.191-197, 2010.

RIBEIRO, V.L.S.; AVANCINI, C.; GONÇALVES, K.; TOIGO, E.; VON POSER, G. Acaricidal activity of Calea serrata (Asteraceae) on Boophilus microplus and Rhipicephalus sanguineus. Veterinary Parasitology, v.151, p.351-354, 2008.

RODRIGUES, I.M.C.; SOUZA FILHO, A.P.S.; FERREIRA, F.A. Estudo fitoquímico de Senna alata por duas metodologias. Planta Daninha, v.27, n.3, p.507-513, 2009.

ROSADO-AGUILAR, J.A.; AGUILAR-CABALLERO, A.; RODRIGUEZVIVAS, R.I.; BORGES-ARGAEZ, R.; GARCIA-VASQUEZ, Z.; MENDEZGONZALEZ, M. Acaricidal activity of extracts from Petiveria alliacea (Phytolaccaceae) against the cattle tick, Rhipicephalus (Boophilus) microplus (Acari: ixodidae). Veterinary Parasitology, v.168, p.299-303, 2010.

SANTOS, F.C.C.; VOGEL, F.S.F.; ROLL, V.F.B.; MONTEIRO, S.G. In vitro effect of the association of citronella, santa maria herb (Chenopodium ambrosioides) and quassia tincture on cattle tick Rhipicephalus (Boophilus) microplus. Ciência Animal Brasileira, Goiânia, v.14, n.1, p.113-119, 2013.

SPINOSA, H.S.; GÓRNIAK, S.L.; BERNARDI, M.M. Farmacologia Aplicada à Medicina Veterinária. 4. ed. Rio de Janeiro: Guanabara Koogan, 2006. 918p. 